\title{
The Role of Mother-Child Secure Attachment and Mother Parenting Styles Toward Social, Emotional and Moral Development in Children Aged 5-6 Years Old
}

\author{
Septani Mula Devi, Prof. Siti Masitoh, Dr. Bachtiar. S.Bachri \\ Universitas Negeri Surabaya \\ Surabaya, Indonesia \\ smuladevi@yahoo.co.id
}

\begin{abstract}
Children's social, emotional and moral development is a development that has a great influence on the children's lives in the community. Mother plays a big role in forming the children's development. The role of mother both quantity and quality in the development are very important because the proper skills of mother determine how well the child monitoring will be performed. This research will focus on children's social, emotional, and moral development in terms of mother's secure attachment and parenting styles perspective. This research is using a qualitative method with research subjects are mothers who have a secure attachment with children aged five-six years old. The result of this study illustrates that mothers who have a secure attachment with their children and nurture their children with democratic parenting style produce children with social, emotional and moral capacities that develop very well.
\end{abstract}

Keywords-A mother-child secure attachment; parenting styles of the mother; social, emotional and moral development of children.

\section{INTRODUCTION}

According to [1] six main components (six core strengths) are considered important pillars to create a healthy, peaceful and prosperous society, and attachment is the initial foundation for a healthy, peaceful and prosperous society which is formed by mutual respect, so there is no desire to harm or persecute each other. This mutual respect arises from a mutual tolerance that respects all the differences and pluralism in society. A society with full of tolerance can arise if every individual has a tendency to have harmony in their social life. All the components of the character as desired in a society apparently require a strong foundation, namely the formation process of close emotional attachment between mother and children since a baby. Adults, who have a strong emotional attachment to their parents since baby, develop into a healthy person in his soul. Parental attachment and children need a mother's big role to nurture them.

[2] Mother-child attachment is a close emotional bond between mother and children. Ainsworth ${ }^{[2]}$ said that attachment is the emotional bond formed by an individual with another specific and binding person in an eternal closeness over time. Ainsworth divided the mother-child attachment into four types: (1) secure attachment, (2) insecurity-resistance, (3) insecuritydoubt, (4) insecurity-insecurity. Secure attachment is a state in which children determined the primary caregiver or mother as a safety guide in exploring the environment [3] The importance of secure attachment of mother and children is in line with the research conducted by [4] (1944) with a report entitled Forty-Four Juvenile Thieves: Those Characters and Home lives that explain how a bad relationship between mother and children can lead to the development of neurosis (psychiatric problems) and the children's bad character.

When we relate children's psychosocial development theory developed by [5] the first stage of human psychosocial development is Trust vs. Mistrust (trust and disbelief). If this first stage (belief) fails to grow well at the age of 0-2 years, then that is embedded in their soul a sense of distrust or mistrust. This trust is the foundation for healthy psychosocial development at a later stage ${ }^{[5]}$. This trust will grow if the nurturing environment is stable, that can create a sense of security and comfort, the baby feels accepted and loved.

Many research results consistently showed that children who have a close attachment to their parents develop into teenagers who have interesting personalities; high selfconfidence, emotional intelligence, and high social skills and ability to solve problems effectively. Simpson et.al ${ }^{[6]}$ conducted a longitudinal study (measuring the attachment of mothers and children at the time of infancy and measured back by the time they reached adulthood), proved that the infant attachment experience had a relative effect permanent inability to form an attachment at later ages.

Children's emotional social development is also greatly influenced by the parenting style. Parenting is how parents treat their children, which parents do, among others, guide, educate, and teach behavior based on the norms that exist in the community. Parenting can be defined as the pattern of interaction between children and the parent that includes the 
fulfillment of physical needs (such as eating, drinking, and clothing) and psychological needs (such as safety, compassion, and protection), as well as children's social norms to live in harmony with their environment ${ }^{[7]}$. In other words, parenting also includes patterns of interaction between parent and children in order to form their character education.

According to [6], parenting patterns are divided into several kinds, namely authoritarian parenting, authoritative, neglectful, and indulgent. The authoritarian parenting pattern will create children with silent characteristics, timid, closed, no initiative and withdrawal from the environment. Authoritative parenting patterns will make children with independent characteristics, have self-control, have a good relationship with friends and cooperative with others. Neglectful parenting pattern will produce children who lack of self-control and cannot cope with independence well. While indulgent parenting will produce children who are aggressive, disobedient, spoiled, and socially mature.

Some of the descriptions above illustrate the importance of mother-child attachment function and parenting patterns in shaping the character of good children. [7] argued that children whose history has close relationships with their parents will have adherence or high commitment to follow the advice of their parents, and are likely to identify themselves according to the values adopted by their parents. Therefore, the source of self-control, integrity and a strong desire to become a moral person is a strong relationship; the growth of a moral identity comes from a history of mother-child safe attachment.

In order for children to have good character and quality they needs to be formed and nurtured from an early age. Early age is the critical period for the formation of individual characters. [8] argued that failure to cultivate social-emotional abilities in a person early on will affect his character in later adulthood. In addition to instilling good morale and character in early childhood is a strategic effort to improve the social condition of the community.

According to [8] children are the only 'building material that is known to form a responsible adult. The phrase indicates that good character must be instilled early on. A study was conducted by the University of Otago, Dunedin New Zeland on 1,000 children studied for 23 years from 1972. Children who were sampled were studied at age 3 and observed in personality and researched at age 18 and 21 years, then reexamined when the children were 26 years old. From the study, it was found that children who, when they were 3 years old, had been diagnosed as an irritable, unruly, and uncontrollable toddlers. When they are 18, they become troubled, aggressive teenagers and have social problems with the community. At the age of 21 , these children find it difficult to foster social relationships with others and those involved with crime. Vice versa, well-adjusted toddlers (3-year-olds), as adults become successful people in the social and healthy life of their souls. The research confirms the importance of good character education in children is done as early as possible.
A mother has such an enormous influence on the development of children because she is the first closest person with children. In this case, mother is the one who conceives, gives birth and raises children. The role of mothers is so great that the development and growth of children depend on the role of the mother itself.

\section{METHOD}

This study uses qualitative methods to better understand what phenomena experienced by the subject of research in the natural context by utilizing natural methods ${ }^{[11]}$. This research was conducted in South Surabaya, Gayungan District. Respondent in this research is a mother who has an educational background of S2 and S3 who care for their children alone because they do not work or work at home and have children aged 5-6 years. Respondents were selected who had a secure attachment to the child and had the Authoritarian, Authoritative, Neglectful and Indulgent parenting types [9]

This research was conducted in South Surabaya, Gayungan District. the location Setting was chosen because the researchers found a phenomenon that a number of mothers who choose to continue their education to a higher level of S2 to S3 but still choose to take care of their own children. The mothers choose to work at home (self-employed) or not to work.

The study was conducted using complete participation observation techniques and in-depth interview techniques to collect data on mother-child safe attachment, mother care pattern and social, emotional and moral development of children. For data triangulation, interviews were conducted for children's class teacher.

Through these techniques, it is expected to get the picture of the interaction data of fulfillment needs of attachment between children and the figure closely intact and deeper. Mother-child attachment was measured using instruments made by researchers based on IPPA (The Inventory of Parent and Peer Attachment) developed by Armsden \& Greenberg (1987), the instrument of determining the parent was constructed based on [6] and instruments social, emotional and moral development of children based on STPPA aged 5-6 years old.

Data analysis used in this research is using Miles and Huberman model [10] Miles and Huberman model divides data analysis in research, based on several stages, data collection, data reduction, data display, and conclusion.

\section{RESULTS AND DISCUSSION}

The subject in the study was a mother who had a safe attachment with her child and had authoritative parenting style. The subject was Mrs. SP (31 years old) and her child KP (5 years old). Mrs. SP was a housewife who runs her own business. Mrs. SP had 4 children with KP as the second child. Mrs. SP was a graduated person of undergraduate and postgraduate from a state university in Surabaya. Mrs. SP 
decided to raise her children on her own together with her husband without assistance from a babysitter. The decision was taken because of her bad experience during raising her first child assisted by a babysitter. The growth of her first child was rather delayed, and he experienced speech delay. With initial awareness of Mrs. SP then she had to take over the nurture of her children without babysitter service.

Mrs. SP's decision to raise her children without babysitter assistance was implemented until her fourth child who was 1 year old. Mrs. SP realized that the quality and quantity of parenting were just as important for the growth of her children. Mrs. SP said, "Currently our children are our mega project, we will use all of the best 'logistics' to support their growth". Mrs. SP accompanied and followed her children's activities. She gave freedom to her children to play but she kept being consistent in implementing the mutually agreed rules. Mrs. SP always discussed with her children about what they wanted and she always expressed her opinion on her children's choices.

KP was the second child of four brothers. KP was a physically active child and independent. During the observation, the researcher found an event when KP was playing with his brothers outside of the house, KP fell down and got his leg injured. KP immediately went into the house and took cotton wetted with water to clean his injury, and then he applied antiseptic on the injury. When the researcher asked KP about what he did, KP answered, "Cleaned the injury and then gave betadine." The researcher asked again, "Oh, how do you know that when you fall down you should clean the injury and give betadine?" KP answered, "Mom always does it whenever I fall down."

The conversation between the researcher and KP above could illustrate how Mrs. SP solved a problem was remembered and implemented well by KP. KP's independence was great that could be concluded when the researcher interviewed Mrs. SP. KP was always delighted to help his mother with any things and he could wash his own eating utensils after he finished eating. KP prepared his school supplies on his own, Mrs. SP just gave instruction to him to prepare his school supplies and then she checked whether the school supplies prepared by him were complete or not.

From the interview with KP's homeroom teacher, KP's homeroom teacher named Mrs. IR said that KP was similar to other children, actively played and could befriend anyone. KP was quite confident but he required motivation to speak in front of the public so as to make his voice loud. KP was delighted to share his packed meal with his friends and he was a type of children who relented whenever he fought over a toy with his friend. Mrs. IR said, "KP will find another toy and leave the toy taken by his friend". However, like common boys, KP liked to play self-defense and run in the classroom. But when his teacher reminded him, he would go back in order despite the laughter with his friends.
For the score of KP's growth at school, his physical growth was average, social growth was average, emotional growth was above average, and independence was above average.

The fulfillment of safe attachment is one of the psychological needs that has proved to affect someone's perspective on the environment since early. The result of field observation shows that a mother who has a safe attachment with her child and has authoritative parenting has a high awareness of the meaning of child in her life that she always strives to give the best in terms of quality and quantity to her child. Something best is not giving everything the child wants, but the mother always thinks what the impact on her child if she implements or gives something to her child.

\section{CONCLUSION}

Based on the result of a study using a qualitative approach, it can be concluded that the fulfillment of need of child attachment is a thing that has to be fulfilled by parents for their children. Safe attachment of a mother and her child has positive implications for the child. In accordance with Erick Erickson's psychosocial theory, human growth on early stage is trust vs mistrust, and the one affecting the growth stage is a safe attachment to the mother or the main caretaker. When the early stage of human growth trust vs mistrust does not develop well, it will affect the next growth. And safe attachment has an important role in the growth stage.

A mother who is aware of her big role in continuing the generation will always think of how to give the best to her children. She will improve her self-quality so as to be a good example for her children. Self-quality is not only in terms of the level of education but also in terms of good characters that will spread to her children because habits in social life and characters are spread by mother to her children, not only taught. Mother has to have all good qualities in herself to be spread to her children. The qualities will spread by the frequency of seeing the mother's behavior. Because it requires a frequency of children seeing mother's good behavior, the mother has to spend more time that can be seen by children, so that children will imitate mother's good behavior, not other caretaker's behavior.

\section{References}

[1] A. Copeland, A. Martin, and M. Walker, "Repo runs: Evidence from the tri-party repo market," J. Finance, vol. 69, no. 6, pp. 2343-2380, 2014.

[2] S. D. Gunarsa, Dasar dan teori perkembangan anak. BPK Gunung Mulia, 1982.

[3] R. Megawangi, "Kelekatan Ibu-Anak 'Kunci Membangun Bangsa."” Bogor (ID): Indonesia Heritage Foundation, 2014.

[4] J. Bowlby, "Forty-four juvenile thieves; their characters and home-life.," 1946.

[5] J. E. Ertle, R. C. Bushong, and W. A. Hillix, "Journal of the History of the Behavioral Sciences," 1977.

[6] D. Baumrind, "Effects of authoritative parental control on child behavior," Child Dev., pp. 887-907, 1966.

[7] G. Kochanska and N. Aksan, "Children's conscience and self-regulation," J. Pers., vol. 74, no. 6, pp. 1587-1618, 2006.

[8] T. Lickona, Educating for character: How our schools can teach respect 
and responsibility. Bantam, 2009.

[9] J. W. Santrock, "Perkembangan anak." Jakarta: Erlangga, 2007.

[10]P. Sugiyono, "Memahami Penelitian Kualitatif," Bandung Alf., 2005. 